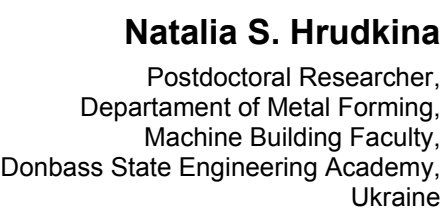

Natalia S. Hrudkina achine Building Faculty, Ukraine

\title{
Process Modeling of Sequential Radial- Direct Extrusion Using Curved Triangular Kinematic Module
}

In this article new engineering calculations such as the value of the relative strain pressure for the combination of a triangular kinematic module with external modules of various configurations are developed. This allowed us to describe qualitatively the nature of the metal flow in the reversal zone before radial extrusion. This made it possible to achieve a decrease in the predicted assessment of the power mode for the deformation process with comparison by the use of rectangular modules. The greatest reduction in the value of the relative strain pressure corresponded to a combination with an adjacent rectangular module (with the missing vertical component $C P V F$ ) and can obtain 7-8\%. The deviation of the theoretical results in the power parameters of the process by using a triangular kinematic module are 12-15\% for a process with a developed flow radial component. The resulting calculations can be used to model new cold extrusion processes.

Keywords: energy method; deformation process; combined extrusion; kinematic module; deformation pressure.

\section{INTRODUCTION}

The diversity of material processing methods allows choosing the most effective method that will ensure high cost-effectiveness of the process and the quality of manufactured parts [1-4]. Recent works concern the study of the possibilities of hot forging, stamping, and longitudinal bending precipitation processes [1-3], the development of theoretical methods for describing the shape of bodies and features of their formation $[4,5]$.

In turn, there is also an intensive development of technology for precise volume stamping (including cold extrusion), which contributes to an increase in production volumes along with the expansion of the range of parts [6-8]. This ensures the production of products with the highest coefficient of metal use and reduces the energy and labor intensity of production. The conducted researches concern traditional methods of cold extrusion (lateral, radial and transverse or longitudinal) [9, 10] and processes of sequential and combined extrusion [5, 11-13]. However, the analysis of force and deformation modes and features of forming and defect formation is performed mainly on the basis of finite element modeling and experimental studies. On the other hand, studies of cold extrusion processes based on various modifications of the energy method of upper estimation are promising.

At the same time, the use of the kinematic module method makes it possible to build computational schemes of the process using a set of unified modules of various shapes [14]. For further evaluation of the power mode, the value of the reduced deformation pressure is

Received: August 2020, Accepted: October 2020

Correspondence to: Dr Natalia S. Hrudkina

Donbass State Engineering Academy, Akademichna

(Shkadinova) Str. 72, 84313 Kramatorsk, Ukraine

E-mail: vm.grudkina@gmail.com

doi: $10.5937 /$ fme2101056H

(C) Faculty of Mechanical Engineering, Belgrade. All rights reserved used. Now there is a problem of expanding the base of known kinematic modules of triangular or trapezoidal shape with inclined (straight or curved) limits. This is due to the need to describe the complex shape of the boundary of the workpiece and tool (the presence of chamfers, curves, edges, etc.) and the complex flow of metal inside the workpiece, for example, during the transition from transverse to longitudinal extrusion in the combined extrusion processes. The use of kinematic modules of complex configuration with inclined borders on the one hand allows us to describe a picture of the metal flow that is close to the real one, on the other hand leads to difficulties in calculations [5, 14, 15]. Therefore, the development of new kinematic modules of triangular shape, techniques for simplifying subsequent calculations and recommendations for their use in the calculation schemes of combined cold extrusion processes is an urgent task. This will help to expand the possibilities of using the energy method for evaluating the power mode and shaping of semi-finished products and to more actively introduce cold combined extrusion processes in production. Currently, the studies of cold extrusion processes are devoted to the works [5-25].

The analysis of the lateral extrusion process based on the upper estimation method using rigid blocks and finite element modeling was carried out in the works [8, 16]. Estimates of the energy parameters of the process were obtained taking into account the presence of a dead zone in the metal reversal zone. The issues of deformability of workpieces, evaluation of step-by-step and boundary (in the sense of limit) forming and defect formation in the processes of combined extrusion are covered in the works $[17,18]$. Calculations of the plasticity resource for the combined radial-direct extrusion process are given in the work [18]. This makes it possible to evaluate the expansion of the technological capabilities of this deformation process. The possibilities of the energy method for obtaining 
analytical dependencies of the force mode of deformation and features of forming in the processes of combined radial-reverse extrusion are demonstrated in the works $[5,15,19,20]$. These studies used the kinematic element method to calculate the value of the reduced strain pressure as the total value for the components of unified modules of rectangular, triangular and trapezoidal shapes. Questions concerning the study of combined sequential radial-longitudinal extrusion processes are still relevant. For the processes of sequential radialdirect extrusion with distribution (the flow of metal from the center of the workpiece to the periphery) from a solid workpiece, "matrix-free extrusion" and methods with a developed radial flow are considered (table 1). Methods of matrix-free extrusion (table 1, row A) are used for the manufacture of deep hollow vessels, which provides a significant reduction in the deformation force in comparison with the use of reverse extrusion [21,22]. Methods of extrusion with a developed component of the radial flow (table 1, row B) are used for the manufacture of sleeves and glasses [23].

\section{Table 1. Schemes of combined sequential radial-direct} extrusion with distribution

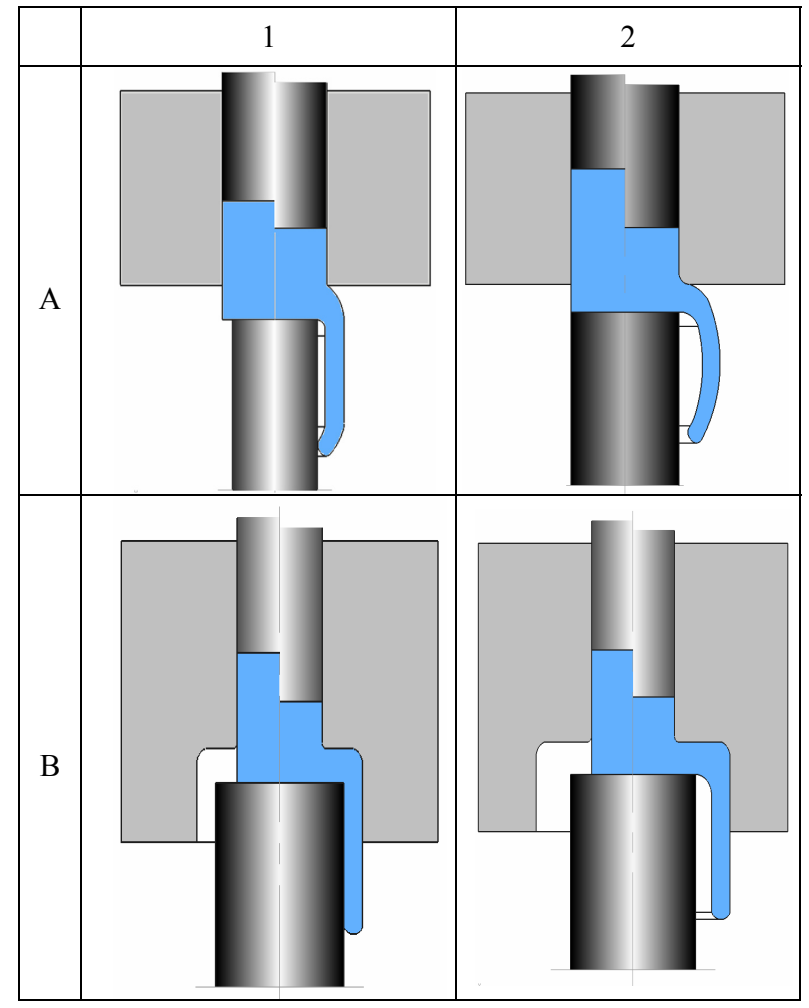

The prospects for using the deformation processes according to the scheme of sequential radial-direct extrusion with distribution are determined by the possibility of reducing the deformation force by reducing the contact area of the active deforming tool with the workpiece.

However, within the framework of using the energy method for evaluating the power mode of the process, there are needs for the development of new kinematic modules with inclined boundaries. This will allow us to describe a complex picture of the interface between the metal flow inside the workpiece in the zone of reversal to the radial flow and at the boundary between the workpiece and the tool. It is also necessary to develop general recommendations on the features and rationality (in comparison with the simplest kinematic modules of rectangular shape) of using kinematic modules of complex shape with inclined borders and their embeddability in new computing schemes.

\section{PRESENTATION OF THE MAIN MATERIAL}

Within the framework of using energy method, the selection of functions describing a kinematically possible velocity field (KPVF) has key significance, satisfying the boundary conditions, the condition of incompressibility of material and the condition of continuity of normal velocity component [24]. The application of the kinematic modules method allows to describe the complex flow schemes with the help of a complex of elementary unified modules [14]. As a total estimate of the reduced pressure is the sum of the reduced pressures of the modules included in this calculation scheme. At the same time, the size and configuration of the deformation center play a decisive role in the construction of KPVF and, as a result, lead to simplification or vice versa complication of subsequent mathematical calculations by calculating the capacity of the forces of deformation, shear and friction. Obtaining an analytical expression of the reduced strain pressure inside the kinematic module provides opportunities for the following optimization for the selected parameter.

Experimental studies of the distortion of the dividing grid in the zone of rotation from direct extrusion to radial (from the center to the periphery) for C46400 material in the process of sequential radial-direct extrusion are shown in Fig. 1. This is considered the process with well-developed radial component of the flow (table 1, row B). The analysis of the nature of the metal flow allows us to draw conclusions about the variants of kinematic modules 2 in the axial zone (Fig. 1). The most used kinematic module in the axial zone of the metal flow reversal is the kinematic module $2 \mathrm{a}$ of rectangular shape $\left(V_{z 2 a}=-V_{0} z / h, V_{r 2 a}=V_{0} /(2 h r)\right)$. However, its using limits the possibilities of the energy method in the optimization of this design scheme based on the geometric parameters of the shape of the deformation cells. As an alternative kinematic module, we can offer a triangular module $2 \mathrm{~b}$ with an inclined line (Fig. 2). The shape of the curve allows us to realize the possibilities of optimizing the reduced strain pressure by the parameter $\alpha \in(0,1)$ [25].

We give the KPVF of triangular kinematic module $2 b[25]$ :

$$
\left\{\begin{array}{l}
V_{z 2 b}=-\frac{\alpha V_{0}}{h} z, \\
V_{r 2 b}=\frac{V_{0}}{2 h} \cdot \frac{R_{1}^{2}(1-\alpha)+\alpha r^{2}}{r} .
\end{array}\right.
$$

View of the curve corresponding to the inclined boundary of the triangular kinematic module $2 \mathrm{~b}$ :

$$
z(r)=\frac{h r^{2}}{R_{1}^{2}(1-\alpha)+\alpha r^{2}},
$$


where $\alpha \in(0,1)$ - optimization parameter that defines the shape of the curve.

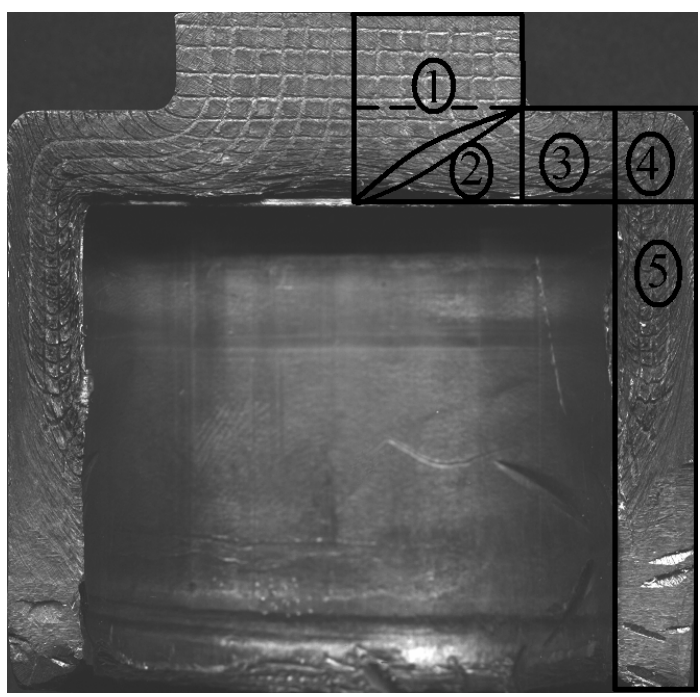

Figure 1. Distortion of the dividing grid in the process of sequential radial-direct extrusion with distribution

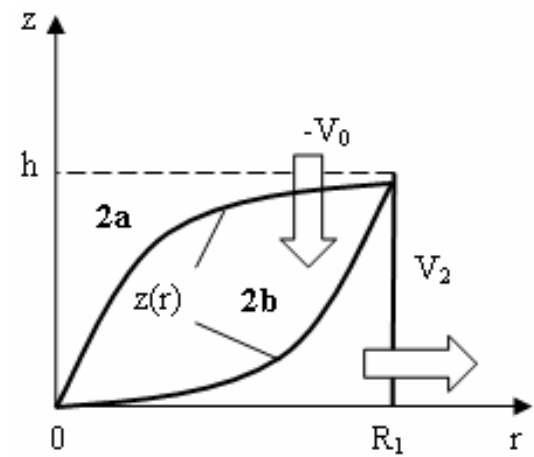

Figure 2. Triangular kinematic module $2 \mathrm{~b}$ with a curved boundary

For generalized scheme of the sequential radialdirect extrusion process various variants of the kinematic module 3 can be considered as adjacent kinematic modules (table 2). Consideration of these kinematic modules as adjacent for $2 \mathrm{a}$ or $2 \mathrm{~b}$ allows us to consider the cases of sequential radial-direct extrusion both for schemes with a developed radial component of the metal flow (module 3a) and with an undeveloped radial metal flow (modules $3 \mathrm{~b}$ and $3 \mathrm{c}$ ). Consideration of the combination of forms of adjacent kinematic modules 2 and 3 will cover practically all possible variants of the process of sequential radial-direct extrusion from a solid workpiece.

The value of the power of the deformation forces in analytical form:

$$
\begin{gathered}
N_{d 2 a}=\pi \sigma_{S} V_{0} R_{1}^{2}, \\
N_{d 2 b}=\frac{2 A \pi \sigma_{S} V_{0}}{\alpha \sqrt{3}}\left[\begin{array}{l}
\sqrt{3} \ln 3-\sqrt{3}+\frac{\sqrt{3}}{1-B^{2}}- \\
-\frac{3}{2} \ln \left|\frac{1+B}{1-B}\right|-\sqrt{3} \ln \left|\frac{\sqrt{3} B-3}{\sqrt{3} B+1}\right|
\end{array}\right],
\end{gathered}
$$

where $A=\frac{R_{1}^{2}(1-\alpha)}{\sqrt{3}}, B=\frac{\sqrt{(1-\alpha)^{2}+3 \alpha^{2}}+\alpha-1}{\alpha \sqrt{3}}$.
Table 2. Configuration of the adjacent kinematic module 3 and KPVF

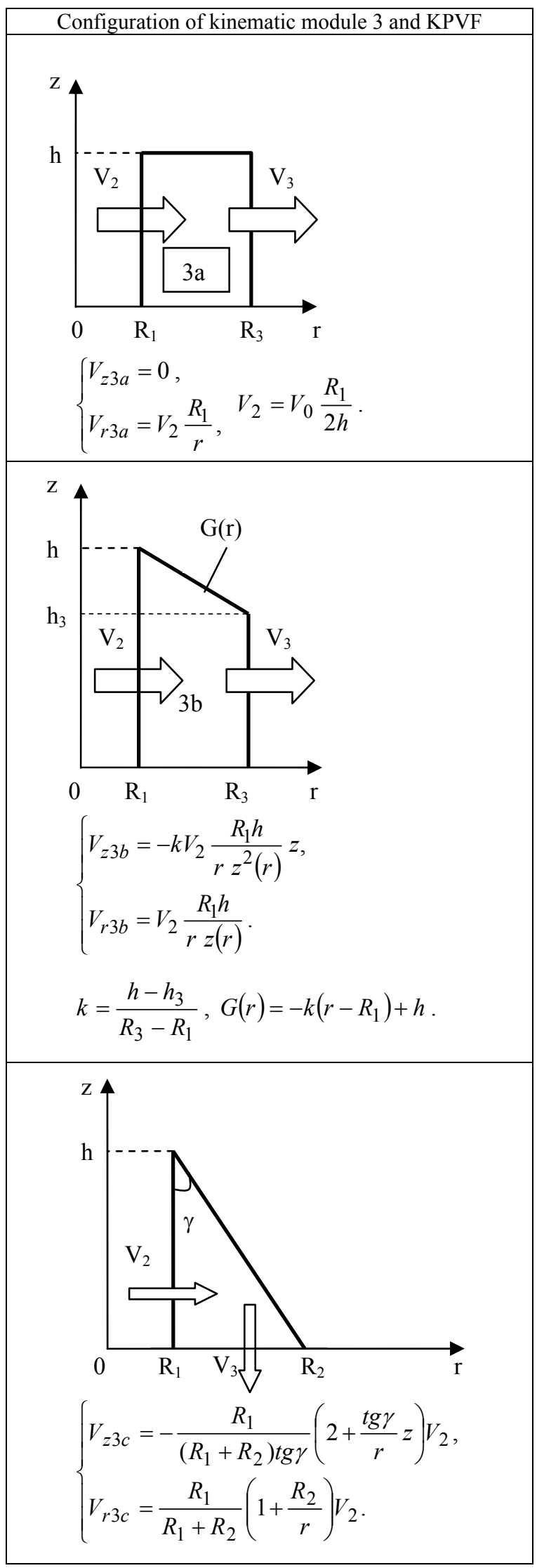

This kinematic module $2 \mathrm{~b}$ can be combined exclusively with the upper rigid module 1 $\left(V_{z 1}=-V_{0}, V_{r 1}=0\right)$, therefore, given (1) - (2), the power value of the slice forces takes the form: 


$$
\begin{gathered}
N_{c 1 \_2 a}=\frac{\pi \sigma_{S} R_{1}^{3} V_{0}}{3 \sqrt{3} h}, \\
N_{c 1_{-} 2 b}=\frac{\pi \sigma_{S} R_{1} h V_{0}}{\sqrt{3}}\left[\begin{array}{c}
\frac{R_{1}^{2}(3-2 \alpha)}{3 h^{2}}+\frac{\operatorname{arctg} C}{2 C \alpha}+ \\
+\frac{(1-\alpha)(2 \alpha-1)}{2 \alpha}
\end{array}\right],
\end{gathered}
$$

where $C=\sqrt{\frac{\alpha}{1-\alpha}}$.

The power value of the friction forces with the tool takes the form:

$$
\begin{gathered}
N_{t 2 a}=\frac{2 \pi \sigma_{S} \mu_{S} R_{1}^{3} V_{0}}{3 \sqrt{3} h}, \\
N_{t 2 b}=\frac{2 \pi \sigma_{S} \mu_{S} R_{1}^{3} V_{0}}{3 \sqrt{3} h}(3-2 \alpha) .
\end{gathered}
$$

The value of the power of the slice forces between modules 2 and 3 takes the form:

$$
\begin{gathered}
N_{c 2 a_{-} 3 a}=\frac{\pi \sigma_{S} R_{1} h}{\sqrt{3}} V_{0}, \\
N_{c 2 b_{-} 3 a}=\frac{\alpha \pi \sigma_{S} R_{1} h}{\sqrt{3}} V_{0}, \\
N_{c 2 a_{-} 3 b}=\frac{\pi \sigma_{S} R_{1} h}{\sqrt{3}} V_{0}\left|\frac{R_{1}}{2 h} \operatorname{tg} \alpha-1\right|, \\
N_{c 2 b_{-} 3 b}=\frac{\pi \sigma_{S} R_{1} h}{\sqrt{3}} V_{0}\left|\frac{R_{1}}{2 h} \operatorname{tg} \alpha-\alpha\right|, \\
N_{c 2 a-3 c}=\frac{\pi \sigma_{S} R_{1} h}{\sqrt{3}} V_{0}\left|\frac{R_{1}\left(3 R_{1}+R_{2}\right)}{2\left(R_{2}^{2}-R_{1}^{2}\right)} \operatorname{tg} \alpha-1\right|, \\
N_{c 2 b_{-} 3 c}=\frac{\pi \sigma_{S} R_{1} h}{\sqrt{3}} V_{0}\left|\frac{R_{1}\left(3 R_{1}+R_{2}\right)}{2\left(R_{2}^{2}-R_{1}^{2}\right)} \operatorname{tg} \alpha-\alpha\right| .
\end{gathered}
$$

The value of the power of the slice forces between modules 2 and 3 takes the form:

From the point of view of studying the possibility of using the parameter $\alpha$ as a variable, it is necessary to consider the value of the reduced pressure, taking into account the power of the deformation, shear and friction forces for various combinations of module 2 and module 3. Taking into account (3) - (14), we consider the value of the reduced pressure:

$$
\bar{p}_{2 i_{-} 3 j}=\frac{N_{d 2 i}+N_{c 1 i_{-} 2 j}+N_{t 2 i}+N_{c 2 i_{-} 3 j}}{\pi \sigma_{s} V_{0} R_{1}^{2}},
$$

where, $i$ takes the value a or $\mathrm{b}$, when using kinematic modules $2 \mathrm{a}$ or $2 \mathrm{~b}$, respectively, $j$ takes the value $\mathrm{a}, \mathrm{b}$ or $\mathrm{c}$, when using kinematic modules $3 \mathrm{a}, 3 \mathrm{~b}$ or $3 \mathrm{c}$, respectively.

In further calculations, we use the relative geometric parameters of the process in the form $\bar{h}=h / R_{2}$, $\bar{h}_{3}=h_{3} / R_{2}, \bar{R}_{3}=R_{3} / R_{2}$. The nature of the change in the value of the reduced deformation pressure $\bar{p}_{2 a_{-} 3 a}$, $\bar{p}_{2 b \_3 a}$ under different friction conditions for a combination of kinematic modules $2 \mathrm{a}$ or $2 \mathrm{~b}$ with module $3 \mathrm{a}$ is shown in fig. 3 .

This combination corresponds to the design schemes of the process of sequential radial-direct extrusion with distribution with a developed component of the radial flow. Deterioration of the friction conditions leads to an increase in the value of the reduced deformation pressure for both combinations of modules $2 \mathrm{a}$ or $2 \mathrm{~b}$ with module $3 \mathrm{a}$. In this case, the red horizontal dotted line determines the value of the reduced strain pressure $\bar{p}_{2 a \_3 a}$ (there is no optimization), and the black solid line corresponds to the value $\bar{p}_{2 b_{-} 3 a}$ with the possibility of optimization by parameter $\alpha \in(0,1)$. Under all conditions of friction, it is rational to use a triangular kinematic module $2 \mathrm{~b}$ instead of a rectangular $2 \mathrm{a}$, while reducing the value of the reduced deformation pressure can be $7-8 \%$ with a decrease under the worst conditions of friction. The optimal value of the parameter $\alpha$ increases with the deterioration of the friction conditions. The influence of other geometric parameters and ratios on the rationality of using a triangular module $2 \mathrm{~b}$ instead of a rectangular module $2 \mathrm{a}$ is presented in the work [25].

The complex shape of the matrix requires the use of kinematic modules of the type $3 \mathrm{~b}$ and $3 \mathrm{c}$ in the calculation schemes of the process of sequential radialdirect extrusion with distribution. The analysis of the rationality of using a triangular kinematic module $2 b$ instead of a rectangular $2 \mathrm{a}$ in combination with the module $3 \mathrm{~b}$ is presented in Fig. 4. For the friction conditions characteristic of cold extrusion processes $\left(\mu_{s}=0.08\right)$ with different ratios of geometric parameters of the deformation process, the value of the reduced deformation pressure has a minimum point. At the same time, this is the optimal value of the reduced strain pressure in comparison with the calculations for the combination of modules $2 \mathrm{a}$ and $3 \mathrm{~b}$. However, if for conditions (9) - (10) it is possible to achieve a reduction in the value $\bar{p}_{2 b \_3 b}$ of the reduced strain pressure to 7 $8 \%$ relative to $\bar{p}_{2 a_{-} 3 b}$, then for conditions $(11)-(12)$ this reduction is insignificant. The optimal value of the parameter $\alpha$ ranges from 0.7 to 0.95 .

The analysis of the rationality of using the triangular kinematic module $2 \mathrm{~b}$ instead of the rectangular $2 \mathrm{a}$ in combination with the module $3 \mathrm{c}$ is presented in fig. 5. For friction conditions $\mu_{s}=0.08$ with different ratios of geometric parameters of the deformation process, the value $\bar{p}_{2 b_{-} 3 c}$ has a minimum point, which determines the optimal value of the reduced deformation pressure in comparison with the calculations for a combination of modules $2 \mathrm{a}$ and $3 \mathrm{c}$. However, the decrease in the value $\bar{p}_{2 b_{-} 3 c}$ of the reduced strain pressure in relation to decreases in comparison with the combination with modules $3 \mathrm{a}$ and $3 \mathrm{~b}$, while for the conditions (13) - (14) this decrease is insignificant (may be $1-2 \%$ ). The optimal value of the parameter $\alpha$ when the value fluctuates $\bar{h}$ 
(the angle of inclination of the edge $\gamma$ ) practically does not change and is in the range from 0.9 to 0.97 .

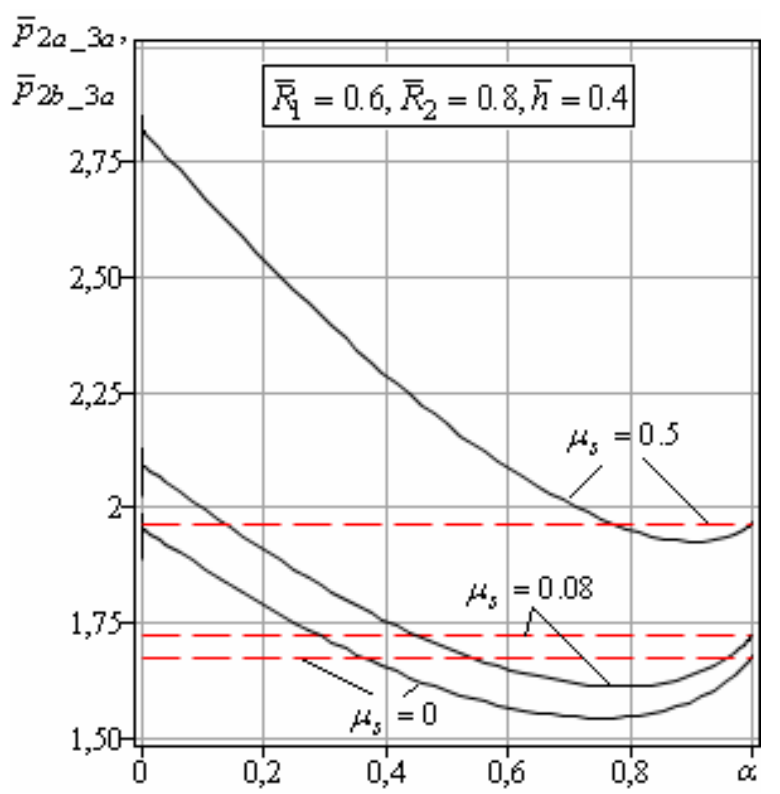

Figure 3. Change in the value of the reduced pressure $\bar{p}_{2 i \quad 3 a}$ under different friction conditions

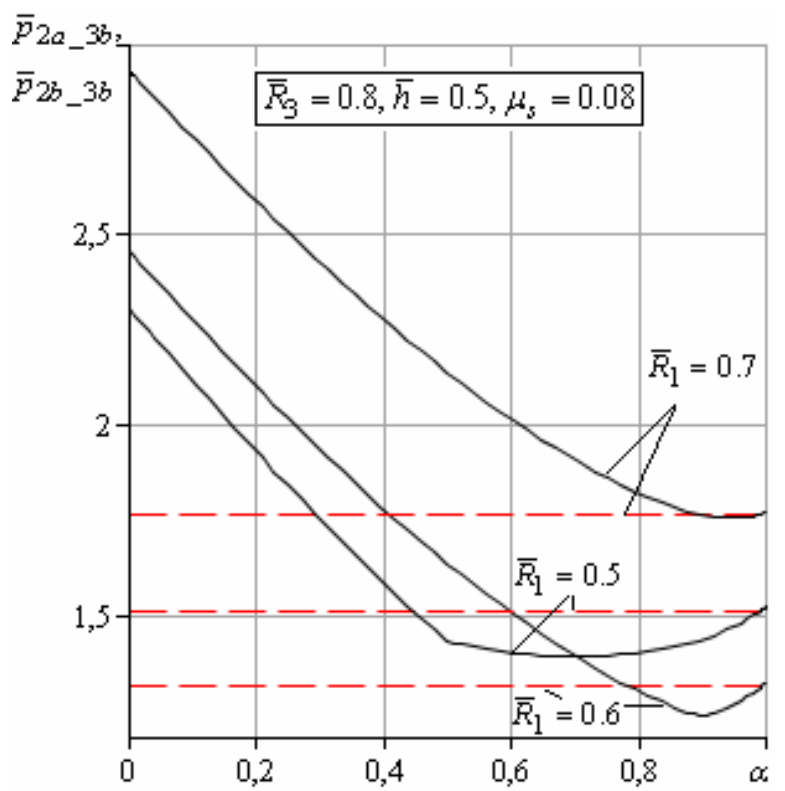

Figure 4. Change in the value of the reduced pressure $\bar{p}_{2 i \quad 3 b}$ under different conditions $\bar{R}_{1}$

This difference in the value of the possible reduction in the estimate of the reduced deformation pressure due to the replacement of a rectangular module $2 \mathrm{a}$ with a triangular module $2 \mathrm{~b}$ occurs due to the different contribution of the cut value on the contact surface of kinematic modules 2 and 3 to the total value of the reduced deformation pressure. The greatest reduction can be achieved by combining the kinematic modules $2 \mathrm{a}$ and $2 \mathrm{~b}$ with the module $3 \mathrm{a}\left(V_{z 3 a}=0\right)$. Less reduction in the value of the reduced strain pressure corresponds to the kinematic modules $3 \mathrm{~b}$ and $3 \mathrm{c}$ with a non-zero component $\operatorname{KPVF}\left(V_{z 3 b}<0\right.$ and $\left.V_{z 3 c}<0\right)$, the direction of which coincides with the direction $V_{z 2 a}$ and $V_{z 2 b}$.

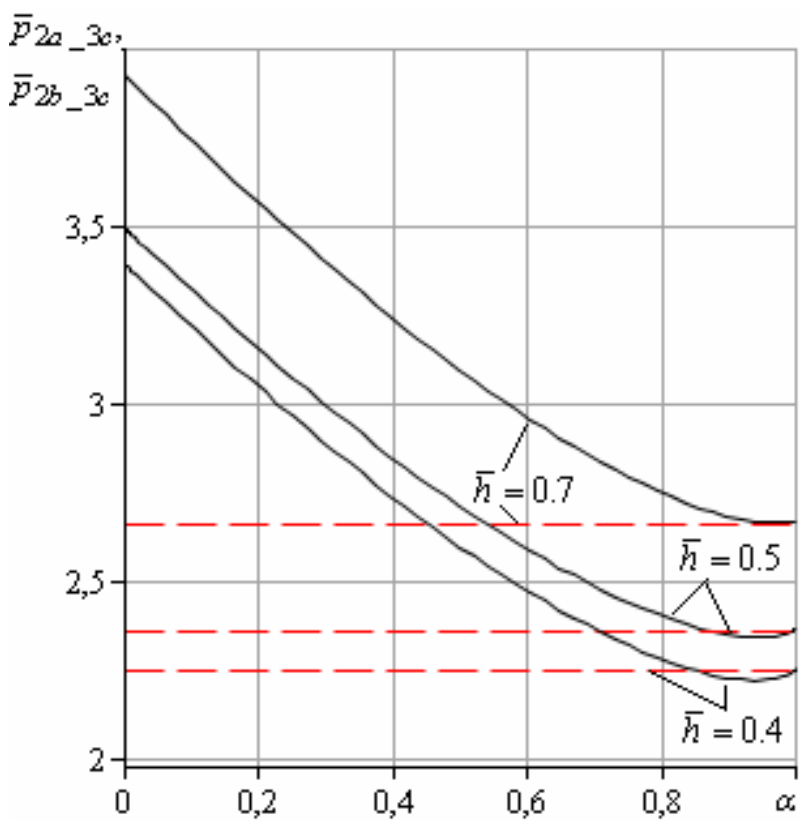

Figure 5. Change in the value of the reduced pressure $\bar{p}_{2 i \_3 c}$ under different conditions $\bar{h}$

Thus, the rationality of using the triangular kinematic module $2 \mathrm{~b}$ instead of a rectangular $2 \mathrm{a}$ in various combinations with modules $3 \mathrm{a}, 3 \mathrm{~b}$ and $3 \mathrm{c}$ due to different ratios and conditions of friction of the deformation process is demonstrated.

Experimental studies on the extrusion of hollow parts by combined radial-direct extrusion with distribution were conducted (Fig. 6). Hollow parts with an external diameter of $28 \mathrm{~mm}$ and $24 \mathrm{~mm}$, made in the process of radial-direct extrusion from aluminum alloys, were obtained. The estimation of the stress-strain state of a billet made of aluminum alloy in the process of deformations, obtained using FEM, and experimental data are given in the work $[23,25]$.
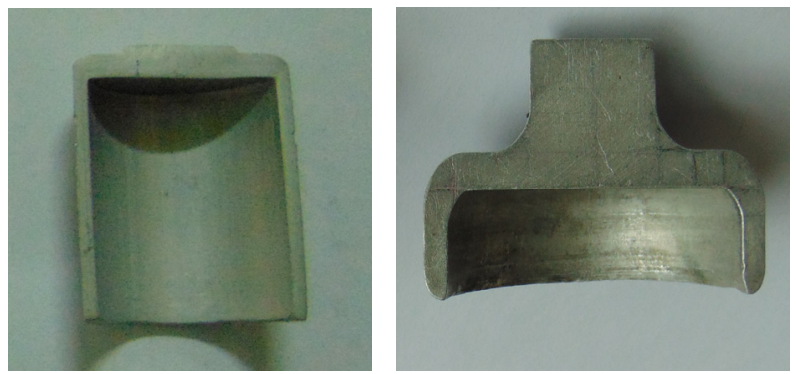

Figure 6. Hollow parts obtained by radially-direct extrusion with distribution

Experimental data on the deformation force of the billet made of aluminum alloy by $R_{1}=7.5 \mathrm{~mm}, R_{3}=12$ $\mathrm{mm}, R_{2}=14 \mathrm{~mm}$ and the initial height of the billet $H_{0}=50$ $\mathrm{mm}$ are shown in figure 7 . The thickness of the flange zone h varied from $2.2 \mathrm{~mm}$ to $5.3 \mathrm{~mm}$, the full working stroke of the punch was $43 \mathrm{~mm}$. The material hardening curve AD1 is approximated by the function $\sigma_{s}=138.4$ $\cdot e^{0.218} \mathrm{MPa}$, the average intensity of accumulated deformation is equal to the given deformation pressure $\mu_{s}=0.04$.

Comparative analysis is performed with the theoretically calculated values for two calculation schemes, including an elementary axial rectangular module $2 \mathrm{a}$ 
and an alternative triangular module $2 \mathrm{~b}$. The deviation of the data obtained for the combination of $2 b-3 a$ (Fig. 7, solid line) and 2a-3a (Fig. 7, dotted line) from the experimentally obtained (Fig. 7, points), amounts 12 $15 \%$ and $15-20 \%$, respectively [25].

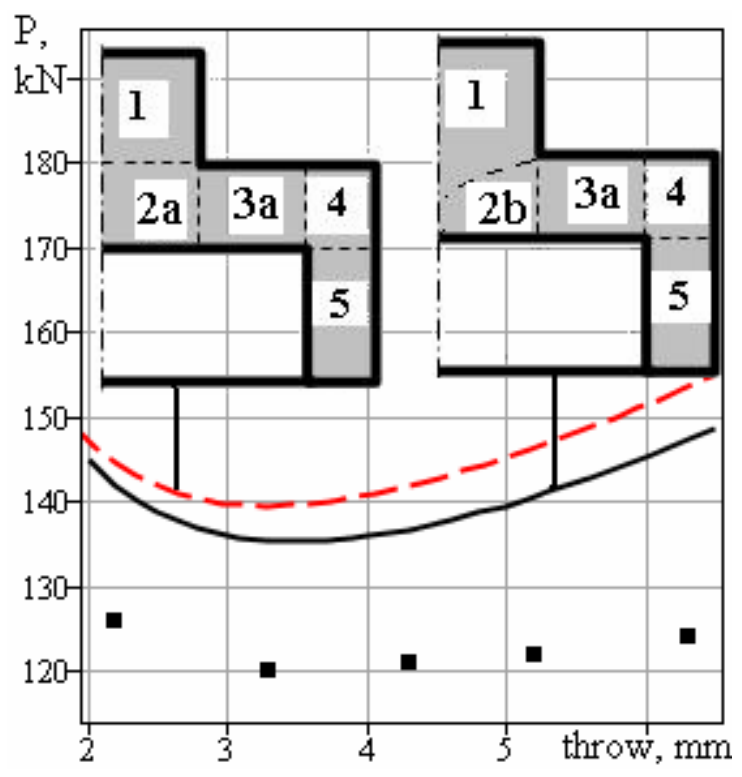

Figure 7. Comparative analysis of experimental and of theoretical data on the extrusion effort due from a press stroke for material AD1

Thus, the rationality of using a triangular kinematic module $2 b$ instead of a rectangular $2 a$ in combination with a module $3 \mathrm{a}$ when evaluating the power parameters of the process of sequential radial-direct extrusion with a distribution with a developed radial component of the flow is confirmed.

\section{CONCLUSIONS}

In this article new engineering calculations of the value of the reduced strain pressure for the combination of a triangular kinematic module with external modules of various configurations are developed. This triangular module with an inclined curved boundary is proposed as an alternative to the elementary rectangular axial module. This allowed us to describe the nature of the metal flow in the reversal zone before radial extrusion, which corresponds to the picture of the curvature of the dividing grid in the process of sequential radial-direct extrusion with distribution. The article analyzes the features of using a triangular kinematic module with an adjacent external module of different configurations. Rectangular, trapezoidal and triangular kinematic modules are selected as neighboring kinematic modules. For each combination of kinematic modules in the axial zone 2 and adjacent external modules, the values of the reduced strain pressure were obtained. A comparative analysis of calculations based on schemes containing an axial rectangular module $2 \mathrm{a}$ (without the possibility of optimization) and an alternative triangular module $2 b$ (with the possibility of optimization by parameter , which determines the shape of the curve). The rationality of using a triangular kinematic module $2 b$ instead of a rectangular module $2 \mathrm{a}$ in combination with adjacent modules of different configurations is established. The greatest reduction in the value of the reduced strain pressure corresponds to a combination with an adjacent rectangular module (with the missing vertical component KPVF) and can reach 7-8\%. For combination with adjacent kinematic modules of trapezoidal and triangular shape, this deviation is reduced due to the presence of a non-zero vertical component of KPVF. A comparative analysis of theoretical and experimental data on the deformation force in the process of sequential radial-direct extrusion with distribution is carried out. The deviation of the theoretically obtained estimates of the power parameters of the process using a triangular kinematic module is $12-15 \%$ for a process with a developed radial component of the flow. The decrease in relation to the design scheme with an axial rectangular module can reach 5-7\%. The calculations of the reduced deformation pressure of a triangular kinematic module in combination with adjacent modules of various configurations can be successfully used for modeling new processes of cold combined extrusion.

\section{REFERENCES}

[1] Markov, O., Gerasimenko, O., Aliieva, L, Shapoval, A.: Development of the metal rheology model of high-temperature deformation for modeling by finite element method, EUREKA: Physics and Engineering, No. 2, pp. 52-60, 2019, doi: 10.21303/2461-4262.2019.00877.

[2] Dragobetskii, V. et al.: Improving the Operational Reliability of Stamped Parts of Electrical Engineering Machines and Electrical Products, Proceedings of the International Conference on Modern Electrical and Energy Systems, No. 8896532, pp. 506-509, 2019, doi: 10.1109/MEES.2019. 8896532.

[3] Kukhar, V., Balalayeva, E., Prysiazhnyi, A., Vasylevskyi, O. and Marchenko, I.: Analysis of relation between edging ratio and deformation work done in pre-forming of workpiece by bulk buckling, MATEC Web of Conferences, Vol. 178, Article Number 02003, 2018, doi: 10.1051/matecconf $/ 201817802003$.

[4] Anishchenko, O.S., Kukhar, V.V., Grushko, A.V., Vishtak, I.V., Prysiazhnyi, A.H., Balalayeva,E.Yu.: Analysis of the Sheet Shell's Curvature with Lame's Superellipse Method during Superplastic Forming, Materials Science Forum, No. 945. pp. 531-537, 2019, doi: 10.4028/www.scientific.net/MSF.945.5 31.

[5] Hrudkina, N., Aliieva, L. Abhari, P., Markov, O., Sukhovirska, L.: Investigating the process of shrinkage depression formation at the combined radial-backward extrusion of parts with a flange, Eastern-European Journal of Enterprise Technologies, Vol. 5, No. 1 (101), pp. 49-57, 2019, doi:10.15587/1729-4061.2019.179232.

[6] Zhang, S.H., Wang, Z.R., Wang, Z.T., Xu, Y. and Chen, K.B.: Some new features in the development of metal forming technology, J. Mater. Process. Technol., Vol. 151, No. 1-3, pp. 39-47, 2004, doi:10.1016/j.jmatprotec.2004.04.098. 
[7] Aliev, I.S.: Radial extrusion processes, Soviet Forging and Sheet Metal Stamping Technology (English Translation of Kuznechno-Shtampovochnoe Proizvodstvo), No. 3, pp. 54-61, 1988.

[8] Bhaduri, A.: Extrusion. In: Mechanical Properties and Working of Metals and Alloys, Springer Series in Materials Science, No. 264. pp. 599-646, 2018, doi: 10.1007/978-981-10-7209-3 13.

[9] Perig, A.: Two-parameter Rigid Block Approach to Upper Bound Analysis of Equal Channel Angular Extrusion through a Segal 20-die, Materials Research-Ibero-American Journal of Materials, Vol. 18, No. 3, pp. 628-638, 2015, doi: 10.1590 /1516-1439.004215.

[10] Luri, R., Luis Pérez, C.J. Modeling of the processing force for performing ECAP of circular crosssection materials by the UBM. Int. J. Adv. Manuf. Technol., No. 58, pp. 969-983, 2012, doi: 10.1007 /s00170-011-3460-x.

[11] Jafarzadeh, H., Zadshakoyan, M., Abdi Sobbouhi, E.: Numerical studies of some important design factors in radial-forward extrusion process, Materials and Manufacturing Processes, Vol. 25, No. 8, pp. 857863, 2010, doi:10.1080/104269109035367 41.

[12] Plancak, M., Barisic, B., Grizelj, B.: Different possibilities of process analysis in cold extrusion, Key Engineering Materials, No.367, pp. 209214, 2008.

[13]Lee, H.Y., Hwang, B.B., Lee, S.H.: Forming load and deformation energy in combined radial backward extrusion process, in: Mori, K., Pietrzyk, M., Kusiak, J. et al.: Metal Forming 2012: proceedings of the 14th International Conference on Metal forming, 16-19.09.2012, AGH University of Science and Technology, Krakow, pp. 487-490.

[14] Aliev, I.S. et al.: The method of kinematic modules for the analysis of precision die forging processes [Metod kinematicheskikh moduley dlya analiza protsessov tochnoy obemnoy shtampovki], in: Materials working by pressure [Sovershenstvovanie protsessov $i$ oborudovaniya obrabotki davleniem $v$ metallurgii i mashinostroenii: sb. nauch. trudov], Donbass State Engineering Academy, Kramatorsk, pp. 142-146, 2001. (in Russian).

[15] Hrudkina, N.S., Aliieva, L.I.: Modeling of cold extrusion processes using kinematic trapezoidal modules, FME Transactions, Vol. 48. No. 2, pp. 357-363, 2020, doi:10.5937/fme2002357H.

[16]Perig, A. V. and Matveyev, I. A.: FEM-Based Deformation Regression Analysis of ECAE Strains, FME Transactions, Vol.47, No.4, pp. 851-855, 2019, doi:10.5937/fmet1904851P.

[17] Ogorodnikov, V.A., Dereven'ko, I.A., Sivak, R.I.: On the Influence of Curvature of the Trajectories of Deformation of a Volume of the Material by Pressing on Its Plasticity Under the Conditions of Complex Loading, Materials Science, No. 54 (3), pp. 326-332, 2018, doi: 10.1007/s11003-018-0188-x.

[18] Dereven'ko, I. A.: Deformability and quality of blanks under conditions of combined shaping [Deformi- ruemost' i kachestvo zagotovok v usloviyah kombinirovannogo formoizmeneniya], in: Materials working by pressure [Obrabotka metallov davleniem], Donbass State Engineering Academy, Kramatorsk, No. 3 (32), pp.80-86, 2012. (in Russian).

[19] Hrudkina, N., Aliieva, L., Markov, O., Marchenko, I., Shapoval, A., Abhari, P., Kordenko, M.: Predicting the shape formation of hollow parts with a flange in the process of combined radial-reverse extrusion, Eastern-European Journal of Enterprise Technologies, Vol. 4, No. 1 (106), pp. 55-62, 2020, doi: 10.15587/1729-4061.2020.203988.

[20]Filippov, Yu.K. et al.: Theoretical study of the combined process of radial and backward extrusion in conical matrix [Teoreticheskoe issledovanie kombinirovannogo protsessa radial'nogo vyidavlivaniya v konicheskoy matritse], Kuznechno-Shtampovochnoe Proizvodstvo (Obrabotka Metallov Davleniem), No. 7., pp. 3-7, 2011. (in Russian).

[21] Renne, I.P., Sumarokova, A.I.: Technological capabilities of the process of free extrusion (without a matrix) of hollow parts [Tehnologicheskie vozmozhnosti processa svobodnogo vydavlivanija (bez matricy) polyh detalej], Kuznechno-shtampovochnoe proizvodstvo, No. 6, pp. 25-26, 1987. (in Russian).

[22] Kalyuzhnyi V.L., Alieva, L.I., Kartamyshev, D.A. and Savchinskii, I.G.: Simulation of Cold Extrusion of Hollow Parts, Metallurgist, Vol. 61, No. 5-6, pp. 359-365, 2017, doi:10.1007/s11015-017-0501-1.

[23] Aliieva, L.I., Kartamyshev, D.O., Grudkina, N.S., Chuchin, O.V.: Technological processes of manufacturing hollow parts on the basis of methods of combined extrusion [Tehnologicheskie processy izgotovleniya polyh detalej na osnove sposobov kombinirovannogo vydavlivaniya], in: Material working by pressure [Obrabotka metallov davleniem], Donbass State Engineering Academy, Kramatorsk, No.1 (46), pp. 22-28, 2018. (in Russian).

[24] Stepansky, L. G.: Calculation of metal-forming processes [Raschetyi protsessov obrabotki metallov davleniem], Mashinostroenie, Moscow, 1979 (in Russian).

[25] Hrudkina, N., Aliieva, L. Markov, O., Kartamyshev, D., Shevtsov, S., Kuznetsov, M.: Modeling the process of radial-direct extrusion with expansion using a triangular kinematic module, Eastern-European Journal of Enterprise Technologies, Vol. 3, No. 1 (105), pp. 17-22, 2020, doi: 10.15587/1729-4061.2020.203989.

\section{NOMENCLATURE}

$V_{0} \quad$ Punch velocity, $[\mathrm{mm} / \mathrm{s}]$

$V_{2} \quad$ Velocity of the metal flow entering module $3,[\mathrm{~mm} / \mathrm{s}]$

$V_{3} \quad$ Velocity of the metal at the exit from

$V_{3}$ module $3,[\mathrm{~mm} / \mathrm{s}]$

$h$ Dimensional thickness of flange at the exit from module $3 \mathrm{a}$, [mm]

$h_{3} \quad$ Dimensional thickness of flange at the exit from module $3 \mathrm{~b}$, [mm] 
$R_{1} \quad$ Dimensional radius of punson, [mm]

$R_{2} \quad$ Dimensional radius of lower base of module $2 \mathrm{c},[\mathrm{mm}]$

$R_{3} \quad$ Dimensional radius at the exit from of module $3 \mathrm{a}$ and $3 \mathrm{~b},[\mathrm{~mm}]$

$\sigma_{\mathrm{s}} \quad$ Yield point, $[\mathrm{MPa}]$

$z(\mathrm{r}) \quad$ Inclined boundary of the flow interface of module $2 b$

$G(\mathrm{r}) \quad$ Inclined boundary of the flow interface of module $3 b$

$V_{r} \quad$ Radial component of direction of KPVF, $[\mathrm{mm} / \mathrm{s}]$

$N_{d 2 b} \quad$ Power of deformation forces of module 2b, [mW] Power shear forces between module 1 and

$N_{c l i \_2 j}$ the possible configurations of module 2 , $[\mathrm{mW}]$

Power shear forces between module 2 and

$N_{c 2 i \_3 j}$ the possible configurations of module 3 , [mW]

$N_{t 2 i} \quad$ Power friction forces, [mW]

$\bar{p}_{2 i \_3 j} \quad$ Reduced dimensionless pressure of power shear forces

\section{Abbreviations}

KPVF Kinematically Possible Velocity Field FEM Finite Element Method

\section{ПРОЦЕС МОДЕЛИРАҢА СЕКВЕНЦИЈАЛНЕ \\ РАДИЈАЛНО-ДИРЕКТНЕ ЕКСТРУЗИЈЕ КОРИШЋЕЊЕМ ЗАКРИВЉЕНОГ ТРОУГЛАСТОГ КИНЕМАТИЧКОГ МОДУЛА}

\section{Н.С. Хрудкина}

Рад приказује нови метод техничког прорачунавања вредности релативног притиска деформације примењеног код комбинације троугластог кинематичког модула са различитим конфигурацијама спољашњег модула. На тај начин је квалитативно описана природа протока метала у зони промене правца пре радијалне екструзије. Остварена је могућност смањења предвиђене процене режима рада пуним искоришћењем снаге у процесу деформације у односу на четвороугле модуле. Највеће смањење вредности релативног притиска деформације остварено је за 7-8\% код комбинације са суседним четвороуглим модулом (без вертикалне компоненте). Одступање од теоријски добијених резултата за параметре снаге, коришћењем троугластог модула, износило је $12-15 \%$ са развијеном радијалном компонентом протока. Прорачунавања се могу применити за моделирање нових процеса хладне екструзије. 